\title{
Can unconditional cash transfers encourage voters to cast ballots? Evidence from elections in Brazil
}

\author{
Victor Araújo*
}

June 30, 2021

\begin{abstract}
Low-income voters are typically underrepresented in elections. Even in countries adopting compulsory voting, there is a consolidated pattern of voter turnout decline among the poor. I argue that implementing an unconditional cash transfer (UCT) can decrease both direct and indirect costs of voting and thus enhance the electoral participation of low-income voters. I test these claims by leveraging Maricá's unconditional cash transfer (MUCT), the largest UCT in Latin America implemented in Brazil in 2013. Causal estimates from a difference-in-differences design show that voter abstention decreased by $15 \%$ after the cash transfer intervention in Maricá. Furthermore, the share of undecided voters - typically those who decide to discard their votes instead of voting for one of the candidates displayed on the ballot - decreased by $33 \%$ after the MUCT implementation. These findings suggest that paying periodic unconditional benefits can mobilize low-income voters and encourage them to participate in elections.
\end{abstract}

Keywords: Unconditional cash transfers; voter abstention; blank votes; general elections; Brazil.

\footnotetext{
${ }^{*}$ University of Zurich (UZH). e-mail:victor . araujo@pw.uzh.ch.
} 


\section{Introduction}

There is a consolidated pattern of voter turnout decline worldwide. In advanced industrial democracies and young democratic regimes, a growing number of people renounce their voting rights each election and stay away from ballot boxes (e.g., Beramendi and Anderson, 2008; Norris, 2012; Schlozman et al., 2013). Even democracies adopting compulsory voting have been experiencing an increase in voter abstention (Katz et al., 2018).

The literature has advanced different (sometimes divergent) explanations ${ }^{1}$ for this voting behavior (Cancela and Geys, 2016). Still, scholars seem to agree that voter abstention is disproportionately concentrated among low-income citizens (e.g., Brady et al., 1995; Highton and Wolfinger, 1998; Lijphart, 2012; Bartels, 2018; Shafer et al., 2021)². These voters are typically underrepresented in the polls and less likely to cast a ballot even in elections with compulsory voting where incentives for participation are higher (Fujiwara, 2015; Cepaluni and Hidalgo, 2016).

In this paper, I study whether unconditional cash transfers (UCTs) encourage voters to cast ballots. UCTs approximate typical universal basic income schemes by transferring a periodic payment for individuals instead of households. These initiatives arise in the specific context of poverty alleviation as substitutes for (or in addition to) the traditional conditional cash transfers (Haushofer and Shapiro, 2016; Berman, 2018). Several UCTs are currently underway worldwide, but there is still scant evidence of their political impacts (Banerjee et al., 2019).

I argue that UCTs can enhance the electoral participation of low-income voters by decreasing the costs of voting. Firstly, UCTs decrease the transportation (mobility) costs that could prevent

\footnotetext{
${ }^{1}$ For a detailed discussion on voter turnout and its drivers, see Blais (2006) and Santana and Aguilar (2021).

${ }^{2}$ Exceptions in the literature are Kasara and Suryanarayan (2015), Häusermann et al. (2018), and Amat and Beramendi (2020).
} 
citizens from turning out to vote. Secondly, UCTs guarantee a paid time for the consumption of political information and engagement in politics before elections. As a result, UCTs reduce voter abstention and the share of voters who typically decide to discard their votes (by casting blank votes) instead of voting for one of the candidates displayed on the ballot.

I test these claims by studying Maricá's unconditional cash transfer ${ }^{3}$ (henceforth MUCT), the largest UCT in Latin America, implemented in Brazil in 2013. The program is financed by revenues from a new oil and gas exploration, Santos Basin pre-salt zone ${ }^{4}$ (henceforth SBPZ), discovered on the coast of Rio de Janeiro state in 2006. MUCT pays a minimum monthly income to 42,000 of the 165,000 (25\%) inhabitants of Maricá, specifically to those who have lived in the municipality for at least three years and earn less than three times Brazil's minimum monthly wage of $\mathrm{R} \$ 1100$ (US\$200). All individuals (children and adults) belonging to families below this income threshold receive an unconditional monthly transfer of $\mathrm{R} \$ 130$ (roughly $12 \%$ of the Brazilian minimum monthly wage).

Currently, MUCT is the only ongoing UCT experiment in the Brazilian state of Rio de Janeiro. I exploit this fact to use other similar municipalities unaffected by this intervention to resemble a counterfactual and estimate the impact of MUCT on voter abstention and the share of blank votes in general elections. MUCT is paid out in Mumbuca, a local currency which can only be used in Maricá. Therefore, the counterfactual is not affected by spillovers created from the program, e.g. beneficiaries sending their benefits to neighbouring municipalities.

Using data from all voting stations in Rio de Janeiro $(\mathrm{N}=177,700)$, I demonstrate that voter abstention in Maricá and the other municipalities in the same state follow parallel trends before the intervention. This finding suggests that electoral participation in Maricá would not have

\footnotetext{
${ }^{3}$ The original name in Portuguese is Renda Básica de Cidadania (RBC).

${ }^{4}$ The pre-salt zone is a tectonic layer in a depth beyond 4-5 km under sea level, topped by a layer of 1-2 $\mathrm{km}$ of salt.
} 
changed in the absence of MUCT. Causal estimates from a difference-in-differences design show that voter abstention decreased 2.8 percentage points (pp), a net decrease of $15 \%$ in general elections held after the intervention. Furthermore, the share of blank (discarded) votes decreased $33 \%$ after the MUCT implementation. About 13\% of registered voters in Maricá (15,565 voters) would not have voted in general elections held in 2014 and 2018 in the absence of MUCT.

I show that this increased electoral participation in Maricá was not driven by formerly demobilized low-income voters willing to reward the political party that created MUCT. I also rule out other alternative mechanisms that could explain the increase in voter turnout. Specifically, I provide evidence that the estimated impact of MUCT cannot be explained by 1) an increase in the share of population at the age when the vote is compulsory; or 2) by an increase in the educational levels in Maricá after MUCT started running.

Furthermore, estimates using a placebo treatment show no evidence of a decrease in voter abstention and the share of blank votes in other municipalities benefiting from oil and gas royalties (but without an unconditional cash transfer). This result indicates that implementing MUCT was crucial to booster political participation in Maricá.

In the remainder of this paper, I first outline potential mechanisms by which UCTs can impact voter abstention in section 2. I then describe MUCT, its characteristics and the context of implementation in section 3. Section 4 presents the data and identification strategies implemented in this paper. Empirical results are reported and discussed in section 5. Section 6 concludes and discusses the implications of findings for the literature. Online appendices A-F provide additional information on data, analyses, and robustness checks. 


\section{Potential channels}

There are costs associated with the act of voting (e.g., Blais et al., 2019). Efforts to get in the voting station and the time spent in casting a ballot are examples of election day costs (direct costs). Moreover, before the election day, voters spend time registering themselves to vote and gathering information about the candidates' proposals and their policy orientation (indirect costs). In this section, I discuss the existent literature and formulate hypotheses on how unconditional cash transfers can decrease both direct and indirect costs of voting and thus stimulate a higher level of electoral participation where this type of benefit is implemented.

\subsection{Direct costs}

The direct costs of voting are often low (Downs, 1957; Aldrich, 1993), but it varies between subgroups of the electorate and tends to be higher for low-income voters (Pettigrew, 2017; Chen et al., 2019; Santana and Aguilar, 2021). Table 1 illustrates this with data from Brazilian general elections. Around $70 \%$ of voters spent less than 15 minutes traveling to their voting stations. Yet, this cost is higher as the income decreases. Among high-income voters $(>\mathrm{R} \$ 5600), 83 \%$ of respondents spent less than 15 minutes traveling to the voting station, against $59 \%$ of individuals in the lowest income group $(<\mathrm{R} \$ 700)$.

The distance to the polling station negatively affects citizens' decision to turn out to vote (Haspel and Knotts, 2005; Brady and McNulty, 2011). Also, low-income voters have fewer incentives to participate in elections because of their perception that the benefits of voting do not outweigh its costs (Cepaluni and Hidalgo, 2016). It is plausible that an unconditional cash transfer would make voters less constrained to participate in politics by decreasing transportation costs and enhancing citizens' mobility on election day. Formally, I expected the following: 
Table 1: Time to arrive in the voting station according to the income groups (2018 Brazilian general elections)

\begin{tabular}{lcccccc}
\hline \hline Income & $<15$ & $15-30$ & $30-45$ & $45-60$ & $>60$ & Total \\
\hline$<\mathrm{R} \$ 700$ & $95(59 \%)$ & $35(22 \%)$ & $9(6 \%)$ & $8(5 \%)$ & $13(8 \%)$ & 160 \\
$\mathrm{R} \$ 701-\mathrm{R} \$ 1100 \dagger$ & $162(62 \%)$ & $64(25 \%)$ & $15(6 \%)$ & $5(2 \%)$ & $13(5 \%)$ & 259 \\
$\mathrm{R} \$ 1101-\mathrm{R} \$ 2200$ & $234(68 \%)$ & $63(18 \%)$ & $20(6 \%)$ & $14(4 \%)$ & $14(4 \%)$ & 345 \\
$\mathrm{R} \$ 2201-\mathrm{R} \$ 3700$ & $123(71 \%)$ & $33(19 \%)$ & $10(6 \%)$ & $1(0.5 \%)$ & $7(4 \%)$ & 174 \\
$\mathrm{R} \$ 3701-\mathrm{R} \$ 5600$ & $56(73 \%)$ & $15(19 \%)$ & $5(6 \%)$ & $1(1 \%)$ & $0(0.0 \%)$ & 77 \\
$>\mathrm{R} \$ 5600$ & $54(83 \%)$ & $7(11 \%)$ & $3(5 \%)$ & $1(1 \%)$ & $0(0.0 \%)$ & 65 \\
\hline Total & 724 & 217 & 62 & 30 & 47 & 1080 \\
\hline \hline
\end{tabular}

Note: †This is the minimum monthly wage in Brazil. Compiled by the author with data from the Americas Barometer (LAPOP-2019), which the sample is representative for all Brazilian regions. The unit of analysis is the individual. The categories displayed in Table 1 comprises the self-reported total household income of respondents.

H1: The payment of an unconditional cash transfer induces a decrease in voter abstention by reducing the direct costs of transportation (mobility)

\subsection{Indirect costs}

The time to invest in politics is unevenly distributed among citizens. Low-income voters tend to be penalized with less time to consume political information and to compare candidates' policy proposals (Bartels, 1996; Lau and Redlawsk, 2001). As a result, even when they show up at the voting stations, those voters are typically less capable of choosing among the options displayed on the ballot (Converse, 2000; Achen and Bartels, 2017; Somin, 2020).

Once again, I use data from Brazilian general elections to illustrate the variation of costs of voting across income groups. As reported in Appendix B, on average, 3.5\% of Brazilians who voted in the 2018 general election have press the option "blank" in the voting machine. This means that voters intentionally discard their votes instead of choosing one of the candidates displayed on the screen. While this may also be a consequence of dissatisfaction with the quality of candidates running in elections (Zucco Jr and Nicolau, 2016), this voting behavior typically 
reflects a lack of political information (Power and Garand, 2007; Driscoll and Nelson, 2014). It is worth noting that $66 \%$ of those discarding their votes in Brazilian elections belong to families at the bottom of the income distribution. Undecided voters are disproportionately concentrated in low-income groups.

When a cash transfer is awarded periodically without conditionalities, citizens have more power to decide where and how to allocate their time (Van Parijs and Vanderborght, 2017). The time (cash) earned from an unconditional cash transfer could be invested by beneficiaries in politics, decreasing the costs of gathering information about the candidates. Those citizens can also use this time earned to mitigate information asymmetry regarding political parties activities and proposals, which could be done by attending arenas (online or in-person) of policy discussion previously inaccessible due to the lack of time. Hence, I expected the following:

H2: The payment of an unconditional cash transfer induces a decrease in blank (discarded) votes by reducing the indirect costs of gathering political information before elections

In this paper, I test these hypotheses leveraging Maricá's unconditional cash transfer, currently the only ongoing UCT experiment in the Brazilian territory and the largest in Latin America. Under some assumptions that I will discuss later in this paper, it allows for estimating the causal effect of an unconditional cash transfer on political participation.

\section{Background}

\subsection{Context}

In 2013, Maricá, a municipality with approximately 165,000 inhabitants and located in the Rio de Janeiro state, implemented the first UCT in Brazil. From a fiscal perspective, this program 
was made possible after the Brazilian federal government discovered a new area for oil and gas exploration in 2006. The exploration of natural resources in the SBPZ placed Brazil among the countries with the most significant oil potential in the world and made it a net oil exporter (da Silva and de Matos, 2016). In 2017, the SBPZ accounted for 50.7\% of Brazil's national oil and natural gas production (Alves et al., 2020). The high-quality oil and the high productivity in this zone make investments attractive (Sauer and Rodrigues, 2016).

Figure 1 shows the location of Maricá in the SBPZ. The municipality is surrounded by Niterói and Saquarema, two other municipalities with higher revenues due to oil and gas royalties. In total, eighteen municipalities (Maricá +17 ) in the Rio de Janeiro state are net beneficiaries of oil and gas exploration in the SBPZ. Despite fluctuations in oil prices, Maricá has experienced a substantive increase in its revenues in the last decade. In 2020, for example, 45\% of Maricá's total revenues was composed of royalties from oil and gas (Alves et al., 2020).

Appendix C shows that Maricá had a total revenue per capita of 1,056 (BRL) in 2003. Ten years later, it was 4,573 (BRL), more than four times larger. In 2016, when Maricá decided to include more individuals in the cash transfer program, its revenue per capita was equivalent to the one observed in other municipalities in the SBPZ, 6,119 (BRL) and 6,430 (BRL), respectively. Although the increase of fiscal capacity played a role in the decision-making, the election of a left-wing party, the Worker's Party (PT), was decisive for Maricá adopting an unconditional cash transfer. 
Figure 1: Santos Basin pre-salt zone (SBPZ) in the Rio de Janeiro state

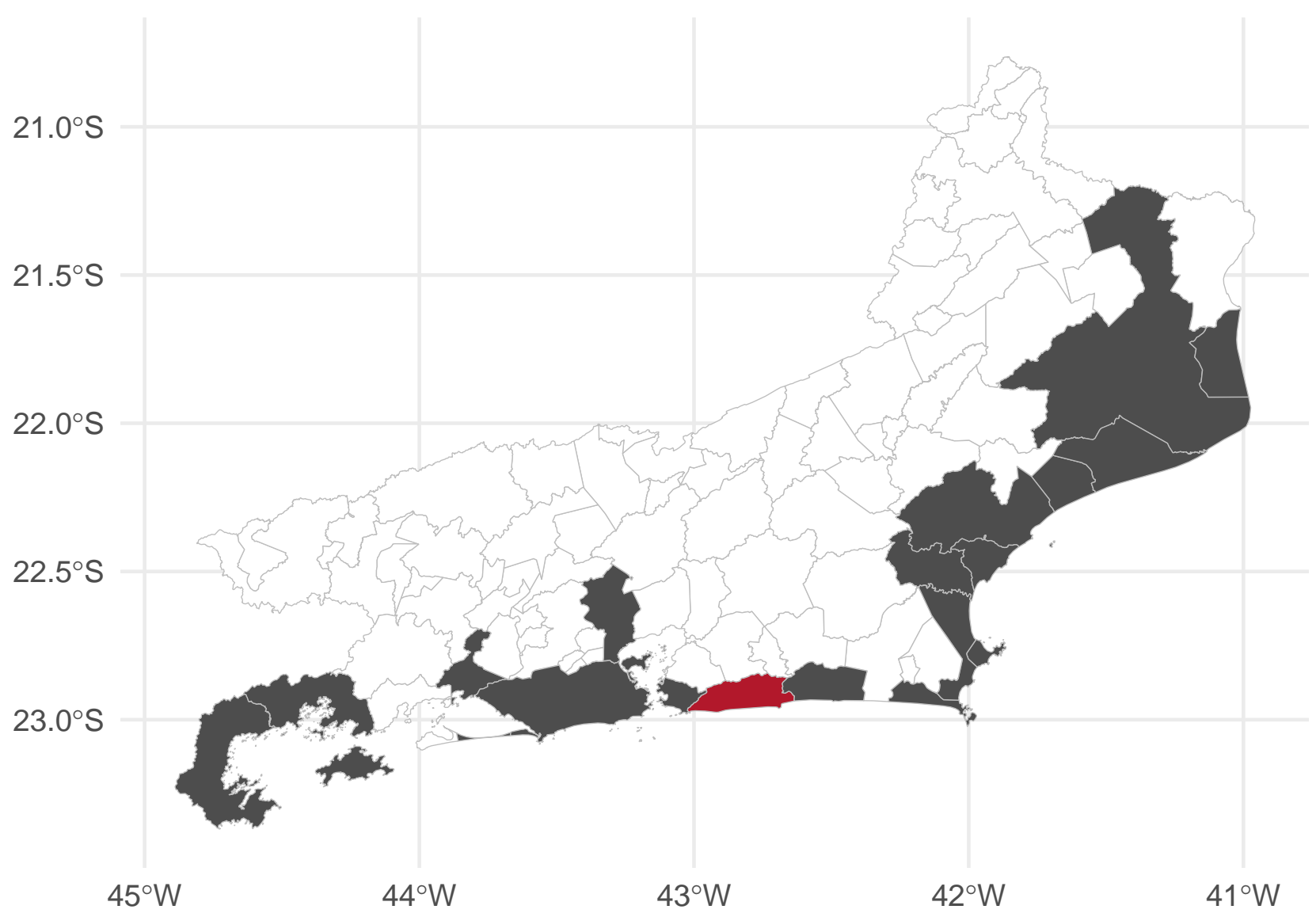

Note: Figure shows all the 92 municipalities in the Rio de Janeiro state. The red one is Maricá; The black ones are the other 17 municipalities (Saquarema, Niterói, Rio de Janeiro, Duque de Caxias, Cabo Frio, Macaé, Casimiro de Abreu, Armação dos Búzios, Carapebus, Rio das Ostras, Quissamã, Itaguaí, Paraty, Angra dos Reis, Campos dos Goytacazes, São João da Barra, Arraial do Cabo) in the SBPZ; The white ones are the municipalities outside of the SBPZ. 


\subsection{The political economy of MUCT}

In the first term of Lula's government (2003-2006), the Brazilian Congress approved legislation ${ }^{5}$ establishing a national universal basic income paid for all Brazilians or foreigners living in Brazil for more than five years regardless of gender, income, or social condition. While the federal government never carried out this program, it served as an inspiration for Maricá to formulate its basic income program some years later.

After winning the 2008 mayoral elections in Maricá, PT sent a bill to the local council to create an unconditional cash transfer. At this time, the opposition had control of the local council, so the proposal did not pass (Freitas and Egydio, 2014). In 2012, the PT candidate (Washington Quaquá) was re-elected to a new term of four years (2013-2016), but this time supported by a majority in the local council.

Starting in January of 2013, public audiences were held with the local population, third sector, religious leaders, and local traders. When sent to the local council again, the project establishing an unconditional cash transfer in Maricá was unanimously approved (Freitas and Egydio, 2014). MUCT was officially created in December of 2013.

\subsection{Eligibility and payments}

MUCT pays a minimum monthly income for those living in Maricá for at least three years and earning less than $R \$ 3300$, three times Brazil's minimum monthly wage of $\mathrm{R} \$ 1100$ (US\$200). Originally conceived as a universal basic income under the law that created the program in $2013^{6}$, MUCT has already reached 42,000 of the 165,000 (25\%) inhabitants of Maricá. While MUCT is still not universal in its coverage, the program approximates a universal basic income

${ }^{5}$ Federal Law 10.835/2004.

${ }^{6}$ Municipal-level Decree law 213/13. 
due to the absence of conditionalities to receive the transfers. All citizens of Maricá below the income threshold of $\mathrm{R} \$ 3300$ can benefit from this program (Silva et al., 2020).

Once officially in the program, each beneficiary receives an identity card issued by Marica's community bank, the Banco Mumbuca. This bank has adopted a local digital currency, called Mumbuca $^{7}$. Beneficiaries can then use this card to buy food and several other items from local stores and merchants that accept Mumbuca in Maricá. Virtually all shops and services in Maricá have been integrated into the program since 2015 (Dektar et al., 2020), but Mumbucas are restricted to Maricá and cannot be used in other localities. In combination, these rules attempt to prevent the rise of inflation and the flight of capital from Maricá to other neighboring municipalities.

Since its creation in 2013, MUCT has featured several different designs. From 2013 to 2016, it paid 85 Mumbucas (the equivalent of $\mathrm{R} \$ 85$ ) per month to roughly 14,000 households. In 2017, MUCT rose to 130 Mumbucas per household per month. In June of 2019, MUCT shifted from a monthly payment of 130 Mumbucas per household to a monthly payment of 130 Mumbucas per individual, bringing the total number of beneficiaries to 42,000 (Dektar et al., 2020). In response to the Covid-19 outbreak, MUCT was increased to 300 Mumbucas in March of 2021. According to the local government, this value will be maintained until August 2021, after which it will be set at 160 Mumbucas.

\footnotetext{
${ }^{7}$ It was chosen in honour of the Mumbuca River located in Maricá. Mumbuca is a name from Tupi, one of the more than 250 languages from Brazilian native populations. In the original Tupi, Mumbuca means "Little black woman".
} 


\section{Empirical strategy}

I adopt a difference-in-difference design leveraging the creation of MUCT. First, I compare the share of voter abstention and blank votes in Maricá with those municipalities in Rio de Janeiro state without an unconditional cash transfer. I then compare Maricá with municipalities in the SBPZ. All municipalities in this area benefited from oil and gas royalties since 2006 and had an equivalent fiscal capacity when MUCT was created in 2013. As I discuss later in this paper, these two strategies reveal similar and consistent results.

\subsection{Data}

In Brazil, voting is compulsory for citizens between the ages of 18 and $70^{8}$. However, the penalty for not voting is a small fine of $\mathrm{R} \$ 3.51$ (US\$ 0.90), so abstention still remains an option (Katz et al., 2018; Turgeon and Blais, 2020). Furthermore, once in the voting station, voters can opt to discard their votes by pressing the option "blank" in the voting machine. This option is typically employed by those who are undecided about their vote choice ${ }^{9}$.

I use data from Brazil's Electoral Court (Tribunal Superior Eleitoral, TSE) to estimate the share of registered voters who did not show up to cast a ballot, as well as the share of blank (discarded) votes in general elections. Every four years, Brazilian citizens elect a president, state governors, legislators for the subnational (state) councils, and legislators for the Brazilian Congress. I collected data from all voting stations in 92 municipalities in the Rio de Janeiro state, from which around 300 were located in Maricá in each election-year. The panel dataset comprises 177,700 observations from six consecutive general elections held in 1998, 2002, 2006,

\footnotetext{
${ }^{8}$ Voting is optional for those between the ages of 16 and 18 or over 70 .

${ }^{9}$ In some cases, the "blank" option can also be used for signalling dissatisfaction with all candidates running in the elections (Zucco Jr and Nicolau, 2016).
} 
2010, 2014, and $2018^{10}$.

I also use data from TSE to calculate: 1) the share of valid votes for PT (the political party that created MUCT); 2) the average level of voters' schooling; and 3) the average age of voters for all the voting stations in the Rio de Janeiro state. For 2 and 3, data is available at the voting station level from 2010 to $2018^{11}$.

\subsection{Checking for parallel trends before the intervention}

The validity of difference-in-difference designs relies on the assumption that a control group approximates the travelling path of the treated units so that the intervention (treatment) is not endogenous (parallel trends assumption). Since we cannot observe this counterfactual conditional expectation, this assumption is untestable by definition (Angrist and Pischke, 2008), and one can assume that the parallel trends assumption holds in the absence of evidence of its violation. Typically, the difference between the treated and control units should be constant over time before the intervention.

Figure 2 plots the voter abstention for three different groups in the Brazilian general elections from 1998 to 2018. The first one, represented by the solid line, is the average abstention in the voting stations in Maricá. The other two lines represent the voter abstention in the rest of the municipalities in the Rio de Janeiro state and the other municipalities located in the SBPZ.

The tendency of voter abstention in the three groups was parallel with negligible differences before MUCT. As shown in Figure 2, there was a shift in this tendency after MUCT. In 2014, when the first general elections held after introducing the unconditional cash transfer, the average

\footnotetext{
${ }^{10}$ Appendix A reports descriptive statistics for all variables used in this paper.

${ }^{11}$ For this reason, statistical models (discussed later in this section) including socio-demographic controls have fewer observations.
} 
Figure 2: Voter abstention in Maricá versus municipalities in the control groups - general elections (1998-2018)

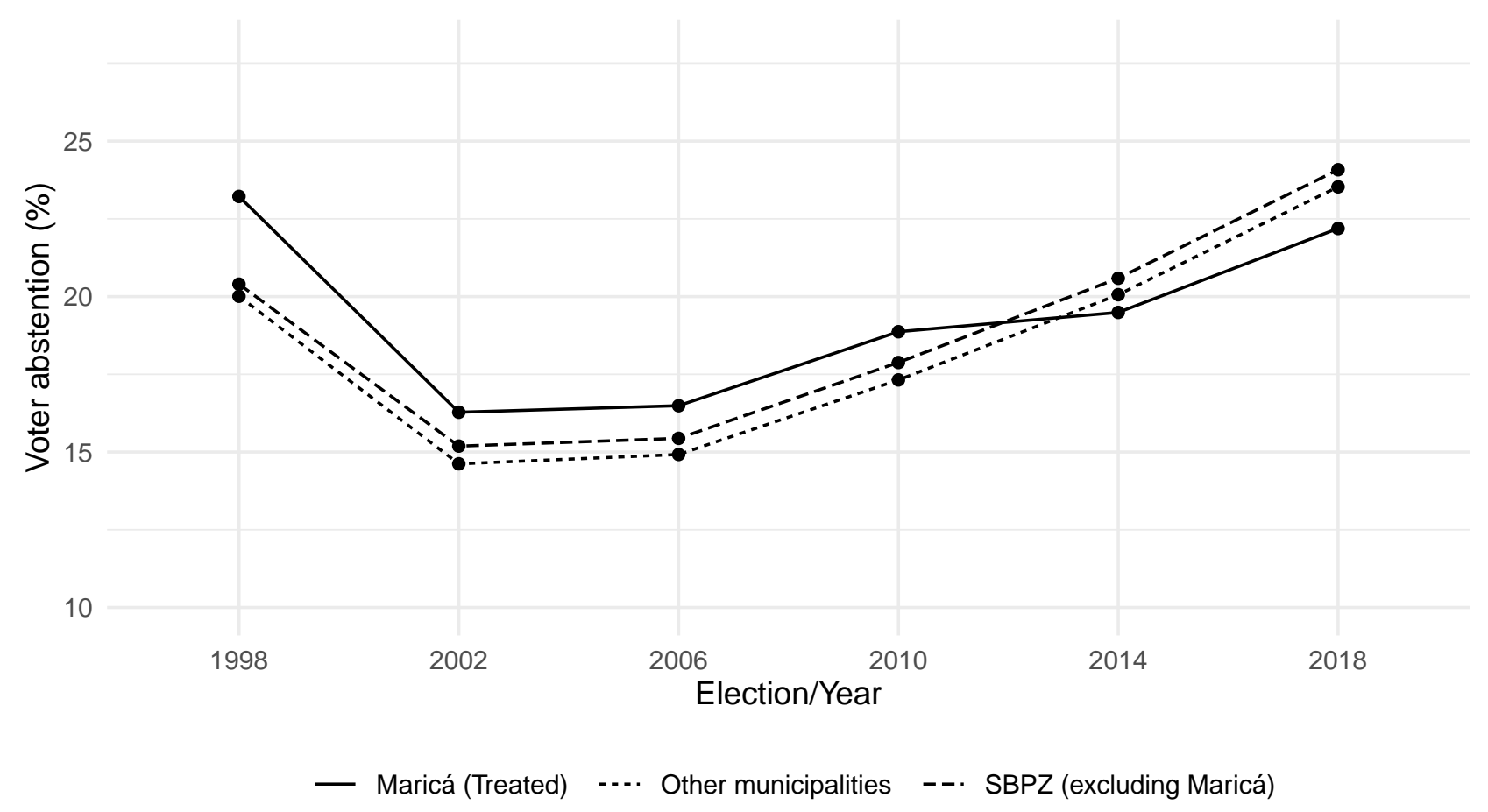

Note: The unit of analysis is the voting station $(\mathrm{N}=177,700)$. The solid line (Treated) refers to the abstention in the voting stations in Maricá. The other two lines correspond to voting stations in the other municipalities in the Rio de Janeiro state $(\mathrm{N}=91)$ and the municipalities in the SBPZ excluding Maricá $(\mathrm{N}=17)$, respectively. 
voter abstention in Maricá was below the other two groups of municipalities for the first time. The visual inspection suggests that this difference between Maricá and the other groups became even more salient fours years later when the 2018 general elections took place. Although there is an overall increasing trend in voter abstention in all municipalities in the Rio de Janeiro state, Maricá has been experiencing a slower decrease in electoral participation after implementing the MUCT in 2013.

\subsection{Identification}

Assuming a constant unit-time fixed effect, I use an ordinary least-squares (OLS) regression model to estimate the causal effect of MUCT on voter abstention and blank votes in the Brazilian general elections.

$$
Y_{i s, t}=\alpha+\beta \text { Treat }_{s}+\gamma \text { PostElec }_{t}+\delta_{r} D D\left(\text { Treat }_{s} \text { X PostElec } t\right)+e_{i s, t}
$$

The unit of analysis, $i$, is the voting station. $s$ denotes the municipality, the level where the treatment occurred, while the $t$ refers to time. Treat is a dummy equal to 1 if the voting station is located in Maricá; Treat controls fixed differences between the units being compared. PostElec is a dummy variable that assumes the value 1 if the general election happened after the intervention in 2013. Time controls for the fact that conditions change over time for all units, whether treated or not. DD is an interaction term created by multiplying Treat and PostElec that indicates voting stations in the post-treatment period.

In difference-in-differences models, conventional standard errors often understate the standard deviation of the estimators. Thereby, standard errors are biased downward (Cunningham, 2018). To account for this, I follow Bertrand et al. (2004) and run models clustering the standard errors 
at the group level (i.e., at the municipal level where the treatment occurred). I also adjust models using municipal-level fixed effects to control for time-invariant unobserved characteristics.

\section{Results}

\section{$5.1 \quad$ Full sample}

Table 2 reports the results using all voting stations in the Rio de Janeiro state. The DD coefficient is the average treatment effect on treatment (ATT), so this is the coefficient that captures the causal effect of MUCT. On average, there was a reduction of 2.8pp (CI 99\% level) of voter abstention in Maricá (model 1). This estimated effect translates into a net average increase ${ }^{12}$ of $15 \%$ of voters casting ballots in Maricá in general elections.

Substantively, it means an addition of 55 voters in each voting station in Maricá ${ }^{13}$. Given that Maricá had 283 voting stations in general election held in 2018, around 13\% of registered voters $^{14}(15,565$ voters) would not have voted in the absence of MUCT. These results corroborate H1 and are robust in the models with clustered standard errors (model 2) and municipal-level fixed effects (model 3).

As anticipated by H2, Table 2 (models 4-6) reports a 0.96pp reduction in the share of blank votes in Maricá, a net decrease of $33 \%$ in the number of undecided voters. Assuming a constant effect across voting stations, about 28\% (33,960) of registered voters in Maricá would have discarded their votes instead of voting for one of the candidates on the ballot in the absence of

\footnotetext{
${ }^{12}$ I use the standard formula of percentage growth to estimate these effects. For example, before the intervention, the average voter abstention was 18.5 in Maricá (starting value). As per models in Table 1, the estimated effect of information exposure is $2.8 \mathrm{pp}$. I use these values in the standard formula of percentage growth by dividing the estimated effect by the starting value: $2.8 / 18.5=.1510 \times 100=15.1$, or roughly $15 \%$.

${ }^{13}$ On average, 365 voters showed up to vote in each voting station in Maricá before the invertention in 2013.

${ }^{14}$ Maricá had 121.577 registered voters in 2018.
} 
Table 2: The effect of MUCT on voter abstention and blank (discarded) votes in general elections (Full sample)

\begin{tabular}{|c|c|c|c|c|c|c|}
\hline & $\begin{array}{c}(1) \\
\text { Abstention }\end{array}$ & $\begin{array}{c}(2) \\
\text { Abstention }\end{array}$ & $\begin{array}{c}(3) \\
\text { Abstention }\end{array}$ & $\begin{array}{c}(4) \\
\text { Blank } \\
\end{array}$ & $\begin{array}{c}(5) \\
\text { Blank } \\
\end{array}$ & $\begin{array}{c}(6) \\
\text { Blank } \\
\end{array}$ \\
\hline Treat & $\begin{array}{c}1.908^{* * *} \\
(0.226)\end{array}$ & $\begin{array}{c}1.908^{* * *} \\
(0.381)\end{array}$ & $\begin{array}{c}1.899^{* * *} \\
(0.300)\end{array}$ & $\begin{array}{c}-0.176^{* * *} \\
(0.0603)\end{array}$ & $\begin{array}{c}-0.176^{* * *} \\
(0.0501)\end{array}$ & $\begin{array}{c}0.0531 \\
(0.0569)\end{array}$ \\
\hline Time & $\begin{array}{l}5.193^{* * *} \\
(0.0293)\end{array}$ & $\begin{array}{c}5.193^{* * *} \\
(0.356)\end{array}$ & $\begin{array}{c}5.193^{* * *} \\
(0.375)\end{array}$ & $\begin{array}{c}0.794^{* * *} \\
(0.00920)\end{array}$ & $\begin{array}{l}0.794^{* * *} \\
(0.0571)\end{array}$ & $\begin{array}{c}0.793^{* * *} \\
(0.0573)\end{array}$ \\
\hline DD (Treat X Time) & $\begin{array}{c}-2.809^{* * *} \\
(0.298)\end{array}$ & $\begin{array}{c}-2.809^{* * *} \\
(0.356)\end{array}$ & $\begin{array}{c}-2.809^{* * *} \\
(0.375)\end{array}$ & $\begin{array}{c}-0.965^{* * *} \\
(0.0828)\end{array}$ & $\begin{array}{c}-0.965^{* * *} \\
(0.0571)\end{array}$ & $\begin{array}{r}-0.963^{* * *} \\
(0.0573)\end{array}$ \\
\hline $\mathrm{R}^{2}$ & 0.155 & 0.155 & 0.154 & 0.046 & 0.046 & 0.046 \\
\hline Obs. & 177700 & 177700 & 177700 & 177700 & 177700 & 177700 \\
\hline N.Clusters & - & 92 & 92 & - & 92 & 92 \\
\hline $\begin{array}{l}\text { Robust SE } \\
\text { Clustered SE } \\
\text { Municipal-level FE }\end{array}$ & $\checkmark$ & $\checkmark$ & $\begin{array}{l}\checkmark \\
\checkmark\end{array}$ & $\checkmark$ & $\checkmark$ & $\begin{array}{l}\checkmark \\
\checkmark\end{array}$ \\
\hline
\end{tabular}

Standard errors in parentheses.

${ }^{*} p<0.10,{ }^{* *} p<0.05,{ }^{* * *} p<0.01$

Note: The unit of analysis is the voting station. Dependent variable is (\%) voter abstention (models 1-3) and the share (\%) of blank (discarded) votes (models 4-6).

MUCT. This result means that not only low-income voters tend to show up more to vote in Maricá, but they are also more likely to choose a candidate on the ballot.

\section{$5.2 \quad$ Restricted sample}

I estimate alternative models using a restricted sample that considers only municipalities in the SBPZ. In this case, instead of comparing Maricá with the other 91 municipalities in the Rio de Janeiro state, I compare Maricá with the other 17 net beneficiaries of oil and gas in the same state. Since municipalities in this area benefited from royalties since 2006 and had an equivalent fiscal capacity when the intervention started in 2013, this is presumably a more conservative estimate of the impact of MUCT on political participation outcomes.

Appendix D shows the results providing additional evidence in favor of H1. On average, 
voter abstention decreased 2.8pp after implementing MUCT, a net increase of $15 \%$ in voter turnout. Once again, this result is stable across estimates and always statistically significant (CI 99\% level). Also, results reported in Appendix D corroborate H2 by reinforcing the impact of MUCT on blank votes. On average, there was a $0.98 \mathrm{pp}$ (a net decrease of $34 \%$ ) reduction in the number of votes discarded in general elections among those casting ballots in Maricá. These findings are in line with the ones reported in Table 2 and provide further evidence that MUCT has slowed down voter abstention and reduced the share of undecided voters.

\subsection{Models with controls}

In this section, I provide estimates with political and sociodemographic controls. As before, I run models with all municipalities in the Rio de Janeiro state and a restricted sample (only municipalities in the SBPZ).

Voters tend to reward politicians when they implement anti-poverty policies (Araújo, 2021). For this reason, formerly demobilized low-income voters could have increased their participation in general elections to reward PT, the political party that created MUCT at the local level. A visual inspection of Figure 3 reveals that this was not the case. In Maricá, PT started experiencing an increase in its electoral performance in general elections in 2006, almost ten years before implementing an unconditional cash transfer in this municipality. Also, before MUCT, the trends of PT's vote share in Maricá and the control groups were not parallel, suggesting that the path of the treated group after the intervention is not attributable to MUCT. Notably, after adopting MUCT, there was a decrease in the share of PT's valid votes for PT in Maricá and not an increase as this alternative hypothesis would suggest. Formal results reported in Appendix E reinforce this descriptive analysis: the inclusion of PT's valid votes in the models 
does not change the main results.

Figure 3: Worker's Party (PT) electoral support in Maricá versus municipalities in the control groups - general elections (1998-2018)

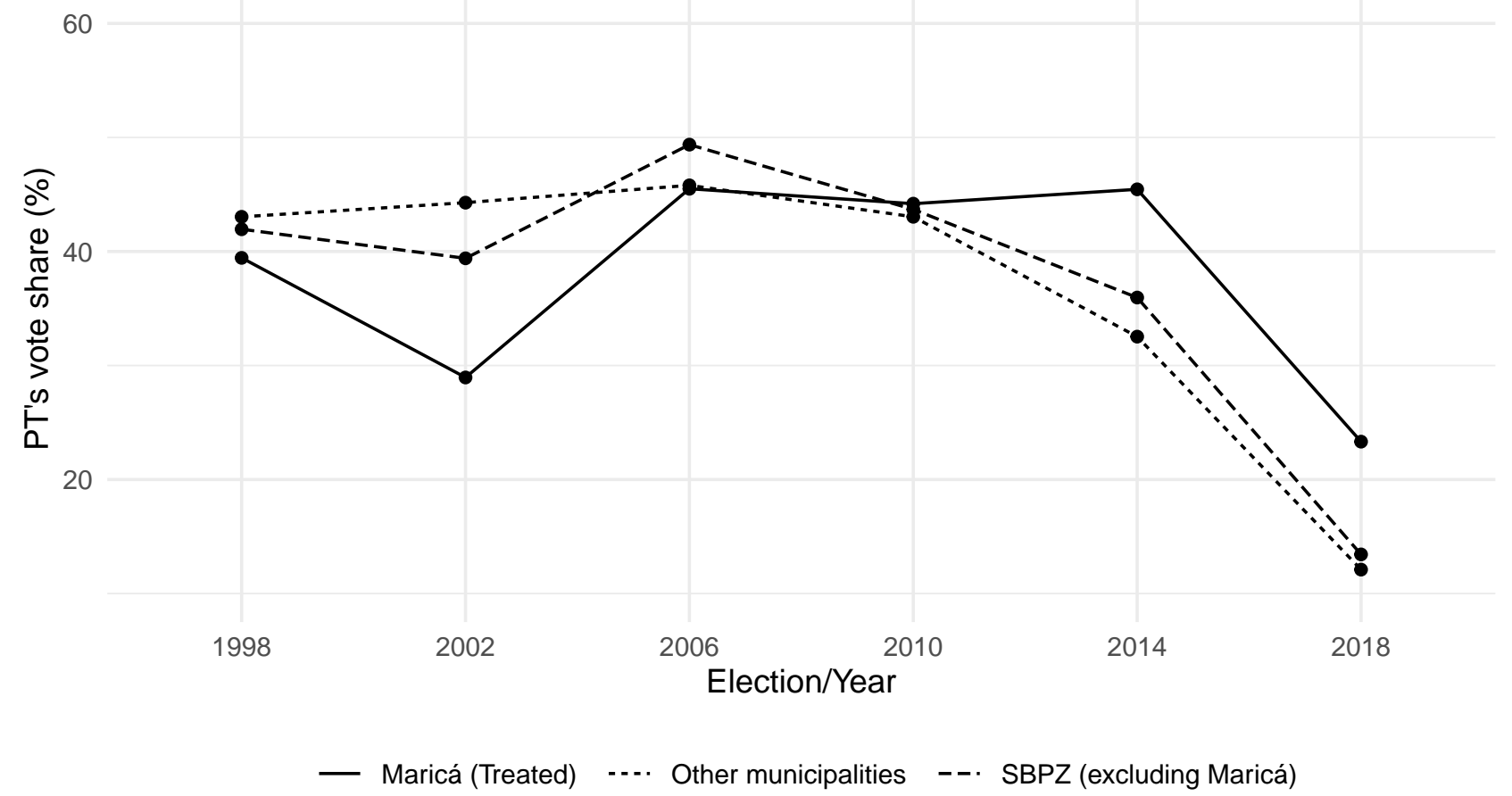

Note: The unit of analysis is the voting station $(\mathrm{N}=177,700)$. The solid line (Treated) refers to the share of valid votes of PT candidates in Maricá. The other two lines correspond to voting stations in the other municipalities in the Rio de Janeiro state $(\mathrm{N}=91)$ and the municipalities in the SBPZ excluding Maricá $(\mathrm{N}=17)$, respectively.

Voter turnout is typically higher among well-educated voters (e.g., Blais et al., 2004; Sondheimer and Green, 2010). Suppose the population of Maricá became better educated at the same time MUCT was implemented. In that case, the observed effect of MUCT on voter abstention could be driven by higher education levels of people registered to vote in this municipality.

Voting is compulsory in Brazil for citizens between the ages of 18 and 70 . But optional for those between the ages of 16 and 18 or over 70 . If during the intervention the population of Maricá became disproportionately distributed between 18 and 70, the estimated effect of MUCT on voter abstention could be a mechanical effect produced by Maricá's demographic characteristics. 
When including sociodemographic controls in the statistical models, I found virtually the same result concerning the impact of MUCT on the share of blank votes, suggesting that controls included in the models play a minor role in explaining the reduction of blank (discarded) votes in Maricá. In the same direction, estimates of the impact of MUCT on voter abstention are always negative and statistically significant, though slightly smaller than before.

\subsection{Models using a placebo treatment}

An alternative way to test the assumption of parallel trends is performing regressions with a "placebo" treatment. For this test, researchers typically estimate new models using a "fake" treatment group, that is, a group that presumably was not affected by the intervention.

I use the other 17 municipalities located in the SBPZ as a placebo treatment group. Once again, I run OLS models to estimate the impact of MUCT on voter abstention and blank votes. In this case, the treatment variable assumes the value 1 if the voting station is located in the SBPZ (excluding Maricá), and 0 otherwise.

Suppose results reported in the previous section are solely driven by MUCT and not also by other potential effects that an increase in revenues induced by the royalties of oil and gas could create. In that case, we should observe no effect of this placebo treatment on the outcome variables. Table 3 reports the results.

There is no indication of a reduction in voter abstention when using this placebo treatment. None of the estimates (models 1-3) is negative and statistically significant. Furthermore, I found no evidence of a decrease in the share of blank votes. The interaction DD (Treat X time) is statistically significant only in the model 4 , but it displays a positive coefficient, which means an increment in the share of blank votes. Appendix F shows that these results hold across different 
specifications also when including sociodemographic controls. These findings corroborate the interpretation that implementing an unconditional cash transfer was determinant for reducing voter abstention and the share of undecided voters in Maricá.

Table 3: The effect of MUCT on voter abstention in general elections (Full sample)

\begin{tabular}{lcccccc}
\hline \hline & $(1)$ & $(2)$ & $(3)$ & $(4)$ & $(5)$ & $(6)$ \\
& Abstention & Abstention & Abstention & Blank & Blank & Blank \\
\hline \multirow{2}{*}{ Treat } & & & & & & \\
& $1.174^{* * *}$ & $1.174^{* *}$ & 0.773 & $-0.0215^{* *}$ & -0.0215 & $0.268^{*}$ \\
Time & $(0.0345)$ & $(0.470)$ & $(0.563)$ & $(0.00942)$ & $(0.0968)$ & $(0.139)$ \\
& $5.177^{* * *}$ & $5.177^{* * *}$ & $5.175^{* * *}$ & $0.771^{* * *}$ & $0.771^{* * *}$ & $0.772^{* * *}$ \\
DD (Treat X Time) & $(0.0421)$ & $(0.278)$ & $(0.277)$ & $(0.0126)$ & $(0.0909)$ & $(0.0912)$ \\
& 0.0345 & 0.0345 & 0.0331 & $0.0430^{* *}$ & 0.0430 & 0.0387 \\
& $(0.0583)$ & $(0.678)$ & $(0.697)$ & $(0.0183)$ & $(0.116)$ & $(0.116)$ \\
\hline $\mathrm{R}^{2}$ & 0.164 & 0.164 & 0.162 & 0.046 & 0.046 & 0.040 \\
Observations & 176518 & 176518 & 176518 & 176518 & 176518 & 176518 \\
N.Clusters & - & 91 & 91 & - & 91 & 91 \\
\hline Robust SE & $\checkmark$ & & & $\checkmark$ & & \\
Clustered SE & & $\checkmark$ & $\checkmark$ & & $\checkmark$ & $\checkmark$ \\
Municipal-level FE & & & $\checkmark$ & & & \\
\hline \hline
\end{tabular}

Standard errors in parentheses

${ }^{*} p<0.10,{ }^{* *} p<0.05,{ }^{* * *} p<0.01$

Note: The unit of analysis is the voting station. Dependent variable is (\%) voter abstention (models 1-3) and the share (\%) of blank (discarded) votes (models 4-6).

\section{Conclusion}

Can unconditional cash transfers encourage low-income voters to cast ballots? Using Maricá's unconditional cash transfer implemented in 2013 as a base, the current paper causally identifies the impact of an unconditional cash transfer (UCT) on political participation.

Causal estimates from a difference-in-difference design reveal that adopting a UCT slowed down the trend of increasing abstention in Maricá, a Brazilian municipality currently running the largest UCT in Latin America. This impact is consistent, robust to several models and 
specifications, and tends to translate into a smaller share of undecided voters - typically those who decide to discard their votes instead of voting for one of the candidates displayed on the ballot.

These findings have implications for several strands of literature in social science. First, evidence from Maricá contradicts the so-called resource curse theory which sustains that natural resources are likely to produce adverse economic and political effects (Sachs and Warner, 2001; Wick and Bulte, 2009). MUCT is an example of a redistributive application of oil and gas royalties in the developing world.

Second, the current paper fills a gap in the literature on the impact of universal basic income programs (UBIs). UCTs approximate typical UBIs in many aspects. First, UCTs are paid to individuals instead of households. Second, beneficiaries are not expected to present any counterpart to keep receiving a periodic cash transfer. Third, as basic income programs, UCTs can empower their beneficiaries by freeing time to be invested in many dimensions of life, such as political participation (Van Parijs, 2004) . Unlike UBIs, UCTs are not universal in their coverage. They have the advantage, however, of working as redistributive transfers with potential effects on poverty and inequality.

Third, existing unconditional cash transfers typically last for relatively short periods (Haushofer and Shapiro, 2016; Gentilini et al., 2019). As of now, MUCT is running for eight years without any prospect of future discontinuation. Local authorities are currently working to extend the program for all Maricá's citizens by the end of 2023, which would place MUCT as the largest universal basic income worldwide. Since developing countries are underrepresented in studies investigating the impacts of basic income programs (Banerjee et al., 2019), findings reported in the current paper can provide insights for scholars and policy-makers. 
Fourth, most impact evaluations focus on economic dimensions such as labour market, drug consumption, family's well-being, and perceptions of satisfaction and happiness (e.g., Berman, 2018; Hoynes and Rothstein, 2019; Kangas et al., 2019; Hamilton and Mulvale, 2019). I show that UCTs can also impact citizens' predisposition to participate in elections. To my knowledge, this is the first study to explore the electoral consequences of a large-scale unconditional cash transfer implemented in a developing country.

Further research should analyze the effect of this type of public resource allocation on other political outcomes. For instance, can UCTs impact peoples' attitudes toward democracy? The implementation of policies with redistributive effects can signal to low-income voters that democratic regimes function and help to improve their welfare (Shafer et al., 2021). Therefore, basic income schemes could improve citizens' evaluations of political institutions and increase the general perception that development is likely under democracy.

Recent literature offers some evidence that clientelism can be eroded by reducing vulnerability. For example, Bobonis et al. (2017) and Frey (2020) find that the supply of water cisterns in drought-prone areas of Brazil weakens clientelism since citizens become less vulnerable and do not depend anymore on selling their votes in exchange for water and health services. However, it is unclear how clientelism and political participation are linked in the context of social policy provision. Future research should investigate whether UCTs, policies with redistributive effects, can decrease the incentives for low-income voters to engage in clientelism. 


\section{References}

Achen, C. and Bartels, L. (2017), Democracy for realists, Princeton University Press.

Aldrich, J. H. (1993), 'Rational choice and turnout', American journal of political science pp. 246-278.

Alves, J. A. B., Schmitz, A. P. and Polette, M. (2020), Efeitos dos royalties do pré-sal sobre o desenvolvimento dos municípios costeiros do sudeste brasileiro, Technical report.

Amat, F. and Beramendi, P. (2020), 'Democracy under high inequality: Capacity, spending, and participation', The Journal of Politics 82(3), 859-878.

Angrist, J. D. and Pischke, J.-S. (2008), Mostly harmless econometrics: An empiricist's companion, Princeton university press.

Araújo, V. (2021), 'Do anti-poverty policies sway voters? evidence from a meta-analysis of conditional cash transfers', Research $\mathscr{E}$ Politics 8(1), 2053168021991715.

Banerjee, A., Niehaus, P. and Suri, T. (2019), 'Universal basic income in the developing world', Annual Review of Economics .

Bartels, L. M. (1996), 'Uninformed votes: Information effects in presidential elections', American Journal of Political Science pp. 194-230.

Bartels, L. M. (2018), Unequal democracy: The political economy of the new gilded age, Princeton University Press.

Beramendi, P. and Anderson, C. J. (2008), Democracy, Inequality, and Representation in Comparative Perspective, Russell Sage Foundation. 
Berman, M. (2018), 'Resource rents, universal basic income, and poverty among alaska's indigenous peoples', World Development 106, 161-172.

Bertrand, M., Duflo, E. and Mullainathan, S. (2004), 'How much should we trust differences-indifferences estimates?', The Quarterly journal of economics 119(1), 249-275.

Blais, A. (2006), 'What affects voter turnout?', Annu. Rev. Polit. Sci. 9, 111-125.

Blais, A., Daoust, J.-F., Dassonneville, R. and Péloquin-Skulski, G. (2019), 'What is the cost of voting?', Electoral Studies 59, 145-157.

Blais, A., Gidengil, E. and Nevitte, N. (2004), 'Where does turnout decline come from?', European journal of political research 43(2), 221-236.

Bobonis, G. J., Gertler, P., Gonzalez-Navarro, M. and Nichter, S. (2017), Vulnerability and clientelism, Technical report, National Bureau of Economic Research.

Brady, H. E. and McNulty, J. E. (2011), 'Turning out to vote: The costs of finding and getting to the polling place', American Political Science Review pp. 115-134.

Brady, H. E., Verba, S. and Schlozman, K. L. (1995), 'Beyond ses: A resource model of political participation', American political science review pp. 271-294.

Cancela, J. and Geys, B. (2016), 'Explaining voter turnout: A meta-analysis of national and subnational elections', Electoral Studies 42, 264-275.

Cepaluni, G. and Hidalgo, F. D. (2016), 'Compulsory voting can increase political inequality: Evidence from brazil', Political Analysis pp. 273-280. 
Chen, M. K., Haggag, K., Pope, D. G. and Rohla, R. (2019), 'Racial disparities in voting wait times: evidence from smartphone data', Review of Economics and Statistics pp. 1-27.

Converse, P. E. (2000), 'Assessing the capacity of mass electorates', Annual review of political science 3(1), 331-353.

Cunningham, S. (2018), Causal inference: The mixtape, Yale University Press.

da Silva, R. D. and de Matos, M. V. M. (2016), 'Petróleo e desenvolvimento regional: o rio de janeiro no pós-boom das commodities', RDE-Revista de Desenvolvimento Econômico 1(1).

Dektar, M., Freitas, F., Katz, P. and Mendes, R. (2020), Informações sobre políticas socioeconômicas de maricá e sua avaliação/information on maricá's socioeconomic policies and their evaluation, Technical report.

Downs, A. (1957), 'An economic theory of political action in a democracy', Journal of political economy $65(2), 135-150$.

Driscoll, A. and Nelson, M. J. (2014), 'Ignorance or opposition? blank and spoiled votes in low-information, highly politicized environments', Political Research Quarterly 67(3), 547-561.

Freitas, H. and Egydio, O. (2014), Programa moeda social mumbuca: Inovação social, digital e econômica, Technical report.

Frey, A. (2020), 'Strategic allocation of irrevocable and durable benefits', American Journal of Political Science .

Fujiwara, T. (2015), 'Voting technology, political responsiveness, and infant health: Evidence from brazil', Econometrica 83(2), 423-464. 
Gentilini, U., Grosh, M., Rigolini, J. and Yemtsov, R. (2019), Exploring universal basic income: A guide to navigating concepts, evidence, and practices, World Bank Publications.

Hamilton, L. and Mulvale, J. P. (2019), “human again": the (unrealized) promise of basic income in ontario', Journal of Poverty 23(7), 576-599.

Haspel, M. and Knotts, H. G. (2005), 'Location, location, location: Precinct placement and the costs of voting', The Journal of Politics 67(2), 560-573.

Häusermann, S., Kurer, T. and Wüest, B. (2018), 'Participation in hard times: how constrained government depresses turnout among the highly educated', West European Politics 41(2), 448471.

Haushofer, J. and Shapiro, J. (2016), 'The short-term impact of unconditional cash transfers to the poor: experimental evidence from kenya', The Quarterly Journal of Economics 131(4), 19732042.

Highton, B. and Wolfinger, R. E. (1998), 'Estimating the effects of the national voter registration act of 1993', Political Behavior 20(2), 79-104.

Hoynes, H. and Rothstein, J. (2019), 'Universal basic income in the united states and advanced countries', Annual Review of Economics 11, 929-958.

Kangas, O., Jauhiainen, S., Simanainen, M., Ylikännö, M. et al. (2019), 'The basic income experiment 2017-2018 in finland: Preliminary results'.

Kasara, K. and Suryanarayan, P. (2015), 'When do the rich vote less than the poor and why? explaining turnout inequality across the world', American Journal of Political Science 59(3), 613-627. 
Katz, G., Levin, I. et al. (2018), 'A general model of abstention under compulsory voting', Political Science Research and Methods 6(3), 489-508.

Lau, R. R. and Redlawsk, D. P. (2001), 'Advantages and disadvantages of cognitive heuristics in political decision making', American Journal of Political Science pp. 951-971.

Lijphart, A. (2012), Patterns of democracy: Government forms and performance in thirty-six countries, Yale University Press.

Norris, P. (2012), Making democratic governance work: How regimes shape prosperity, welfare, and peace, Cambridge University Press.

Pettigrew, S. (2017), 'The racial gap in wait times: why minority precincts are underserved by local election officials', Political Science Quarterly 132(3), 527-547.

Power, T. J. and Garand, J. C. (2007), 'Determinants of invalid voting in latin america', Electoral Studies 26(2), 432-444.

Sachs, J. D. and Warner, A. M. (2001), 'The curse of natural resources', European economic review 45(4-6), 827-838.

Santana, A. and Aguilar, S. (2021), 'How costly is voting? explaining individual differences in the costs of voting', Journal of Elections, Public Opinion and Parties 31(1), 119-139.

Sauer, I. L. and Rodrigues, L. A. (2016), 'Pré-sal e petrobras além dos discursos e mitos: disputas, riscos e desafios', Estudos avançados 30(88), 185-229.

Schlozman, K. L., Verba, S. and Brady, H. E. (2013), The unheavenly chorus: Unequal political voice and the broken promise of American democracy, Princeton University Press. 
Shafer, J., Cantoni, E., Bellettini, G. and Ceroni, C. B. (2021), 'Making unequal democracy work? the effects of income on voter turnout in northern italy', American Journal of Political Science 85(3), 1044-1062.

Silva, S. P., Morais, L. P. and Santos, D. S. (2020), 'Repertório programático e resiliência das políticas subnacionais de economia solidária no brasil: síntese de experiências estaduais e municipais'.

Somin, I. (2020), Democracy and political ignorance, Stanford University Press.

Sondheimer, R. M. and Green, D. P. (2010), 'Using experiments to estimate the effects of education on voter turnout', American Journal of Political Science 54(1), 174-189.

Turgeon, M. and Blais, A. (2020), 'Am i obliged to vote? a regression discontinuity analysis of compulsory voting with ill-informed voters', Political Science Research and Methods pp. 1-7.

Van Parijs, P. (2004), 'Basic income: a simple and powerful idea for the twenty-first century', Politics 8 Society 32(1), 7-39.

Van Parijs, P. and Vanderborght, Y. (2017), Basic income: A radical proposal for a free society and a sane economy, Harvard University Press.

Wick, K. and Bulte, E. (2009), 'The curse of natural resources', Annu. Rev. Resour. Econ. 1(1), 139-156.

Zucco Jr, C. and Nicolau, J. M. (2016), 'Trading old errors for new errors? the impact of electronic voting technology on party label votes in brazil', Electoral Studies 43, 10-20. 
Can unconditional cash transfers encourage voters to cast ballots?

\author{
Evidence from elections in Brazil
}

\title{
Online Appendix
}

\author{
Victor Araújo*
}

${ }^{*}$ University of Zurich. e-mail:victor.araujo@pw.uzh.ch. 


\section{Contents}

$\begin{array}{ll}\text { A Descriptive statistics } & 3\end{array}$

B Voting options in general elections by income groups 4

C Revenue per capita by groups of municipalities in the Rio de Janeiro state 5

$\begin{array}{lr}\text { D Models using a restricted sample - general elections } & 6\end{array}$

$\begin{array}{llr}\text { E Models with controls - general elections } & 7\end{array}$

E.1 Full sample . . . . . . . . . . . . . . . . . . . . . . 7

E.2 Restricted sample . . . . . . . . . . . . . . . . . . . . . . 8

$\begin{array}{ll}\text { F Models with a placebo treatment } & 9\end{array}$

F.1 With controls . . . . . . . . . . . . . . . . . . . . . . 9 


\section{A Descriptive statistics}

Table 1: Descriptive statistics

\begin{tabular}{lccccc}
\hline \hline Variable & Obs & Mean & Std.Dev. & Min & Max \\
\hline & & & & & \\
Voter abstention & 177,700 & 18.59 & 6.371 & 0 & 98.73 \\
Blank (discarded) votes & 177,700 & 3.344 & 1.789 & 0 & 22.22 \\
Treat & 177,700 & 0.006 & 0.081 & 0 & 1 \\
PT valid votes & 177,679 & 36.55 & 16.16 & 0.457 & 94.51 \\
Age (avg.) & 97,368 & 46.97 & 6.475 & 17 & 72.16 \\
Schooling (avg.) & 97,368 & 4.406 & 0.683 & 1.814 & 7.185 \\
\hline \hline
\end{tabular}

Note: Compiled by the author with data from the Tribunal Superior Eleitoral (Superior Electoral Court, TSE).

The unit of analysis is voting station. 


\section{B Voting options in general elections by income groups}

Table 2: Voting options by income groups (2018 Brazilian general elections)

\begin{tabular}{lcccccc}
\hline \hline Income & Frontrunner & Second place & Third place & Other & Blank & Null \\
\hline$<\mathrm{R} \$ 700$ & $61(46 \%)$ & $46(35 \%)$ & $5(3.8 \%)$ & $10(7.5)$ & $5(4 \%)$ & $5(4 \%)$ \\
$\mathrm{R} \$ 701-\mathrm{R} \$ 1100 \dagger$ & $123(53 \%)$ & $57(24 \%)$ & $16(7.0)$ & $13(6 \%)$ & $9(4 \%)$ & $11(5 \%)$ \\
$\mathrm{R} \$ 1101-\mathrm{R} \$ 2200$ & $167(53 \%)$ & $78(25 \%)$ & $21(7 \%)$ & $25(8 \%)$ & $8(2 \%)$ & $12(4 \%)$ \\
$\mathrm{R} \$ 2201-\mathrm{R} \$ 3700$ & $102(64 \%)$ & $28(18 \%)$ & $11(7 \%)$ & $10(6 \%)$ & $6(4 \%)$ & $1(0.5)$ \\
$\mathrm{R} \$ 3701-\mathrm{R} \$ 5600$ & $40(55 \%)$ & $10(13 \%)$ & $8(11 \%)$ & $8(11 \%)$ & $4(5 \%)$ & $3(4 \%)$ \\
$>\mathrm{R} \$ 5600$ & $37(60 \%)$ & $11(18 \%)$ & $4(6.5 \%)$ & $5(8 \%)$ & $1(2 \%)$ & $3(5 \%)$ \\
\hline Total & 530 & 230 & 65 & 71 & 33 & 35 \\
\hline \hline
\end{tabular}

Note: fis the minimum monthly wage in Brazil. Compiled by the author with data from the Americas Barometer (LAPOP-2019), which the sample is representative for all Brazilian regions. The unit of analysis is the individual. The categories displayed in Table 2 comprises the self-reported total household income of respondents. 


\section{Revenue per capita by groups of municipalities in the}

\section{Rio de Janeiro state}

Figure 1: Total revenue per capita by groups of municipalities in the Rio de Janeiro state

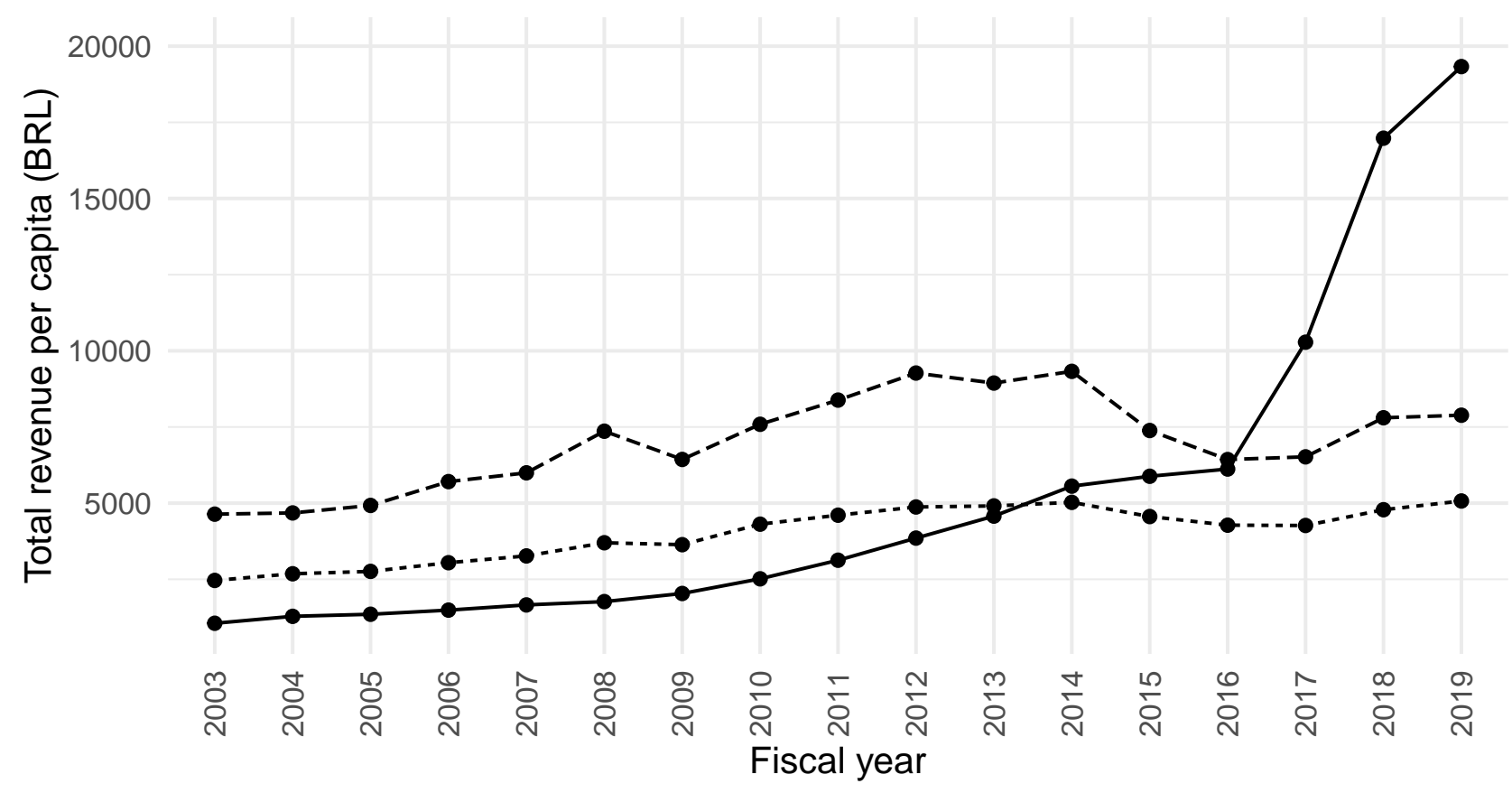

\section{— Maricá -... Others --. Pre-salt zone (excluding Maricá)}

Note: The unit of analysis is municipality $(\mathrm{N}=92)$. Pre-salt zone $(\mathrm{N}=17)$ is composed by the following municipalities in the Rio de Janeiro state: Saquarema,Niterói, Rio de Janeiro, Duque de Caxias, Cabo Frio, Macaé, Casimiro de Abreu, Armaçãodos Búzios, Carapebus, Rio das Ostras, Quissamã, Itaguaí, Paraty, Angra dosReis, Campos dos Goytacazes, São João da Barra, Arraial do Cabo. 


\section{Models using a restricted sample - general elections}

Table 3: The effect of MUCT on voter abstention in general elections (Full sample)

\begin{tabular}{|c|c|c|c|c|c|c|}
\hline & $\begin{array}{c}(1) \\
\text { Abstention }\end{array}$ & $\begin{array}{c}(2) \\
\text { Abstention }\end{array}$ & $\begin{array}{c}(3) \\
\text { Abstention } \\
\end{array}$ & $\begin{array}{c}(4) \\
\text { Blank } \\
\end{array}$ & $\begin{array}{c}(5) \\
\text { Blank } \\
\end{array}$ & $\begin{array}{c}(6) \\
\text { Blank }\end{array}$ \\
\hline Treat & $\begin{array}{c}1.378^{* * *} \\
(0.227)\end{array}$ & $\begin{array}{c}1.378^{* * *} \\
(0.384)\end{array}$ & $\begin{array}{c}1.267^{* * *} \\
(0.454)\end{array}$ & $\begin{array}{c}-0.166^{* * *} \\
(0.0604)\end{array}$ & $\begin{array}{l}-0.166^{* *} \\
(0.0717)\end{array}$ & $\begin{array}{l}-0.170 \\
(0.125)\end{array}$ \\
\hline Time & $\begin{array}{l}5.211^{* * *} \\
(0.0403)\end{array}$ & $\begin{array}{c}5.211^{* * *} \\
(0.633)\end{array}$ & $\begin{array}{c}5.208^{* * *} \\
(0.655)\end{array}$ & $\begin{array}{l}0.814^{* * *} \\
(0.0132)\end{array}$ & $\begin{array}{l}0.814^{* * *} \\
(0.0732)\end{array}$ & $\begin{array}{l}0.810^{* * *} \\
(0.0736)\end{array}$ \\
\hline DD (Treat X Time) & $\begin{array}{c}-2.827^{* * *} \\
(0.300)\end{array}$ & $\begin{array}{c}-2.827^{* * *} \\
(0.633)\end{array}$ & $\begin{array}{c}-2.824^{* * *} \\
(0.655)\end{array}$ & $\begin{array}{c}-0.984^{* * *} \\
(0.0834)\end{array}$ & $\begin{array}{c}-0.984^{* * *} \\
(0.0732)\end{array}$ & $\begin{array}{c}-0.981^{\text {*** }} \\
(0.0736)\end{array}$ \\
\hline $\mathrm{R}^{2}$ & 0.155 & 0.155 & 0.155 & 0.046 & 0.046 & 0.045 \\
\hline Obs. & 97782 & 97782 & 97782 & 97782 & 97782 & 97782 \\
\hline N.Clusters & - & 18 & 18 & - & 18 & 18 \\
\hline $\begin{array}{l}\text { Robust SE } \\
\text { Clustered SE } \\
\text { Municipal-level FE }\end{array}$ & $\checkmark$ & $\checkmark$ & $\begin{array}{l}\checkmark \\
\checkmark\end{array}$ & $\checkmark$ & $\checkmark$ & $\begin{array}{l}\checkmark \\
\checkmark\end{array}$ \\
\hline
\end{tabular}

Standard errors in parentheses

${ }^{*} p<0.10,{ }^{* *} p<0.05,{ }^{* * *} p<0.01$

Note: The unit of analysis is the voting station. Dependent variable is (\%) voter abstention (models 1-3) and the share (\%) of blank (discarded) votes (models 4-6). 


\section{E Models with controls - general elections}

\section{E.1 Full sample}

Table 4: The effect of MUCT on voter abstention in general elections (Full sample)

\begin{tabular}{lcccccc}
\hline \hline & $(1)$ & $(2)$ & $(3)$ & $(4)$ & $(5)$ & $(6)$ \\
& Abstention & Abstention & Abstention & Blank & Blank & Blank \\
\hline \multirow{2}{*}{ Treat } & $1.259^{* * *}$ & $1.259^{* * *}$ & 0.213 & -0.143 & -0.143 & $0.658^{* * *}$ \\
& $(0.242)$ & $(0.307)$ & $(0.555)$ & $(0.104)$ & $(0.203)$ & $(0.159)$ \\
Time & $-0.138^{* *}$ & -0.138 & 0.186 & $1.645^{* * *}$ & $1.645^{* * *}$ & $1.782^{* * *}$ \\
& $(0.0541)$ & $(0.320)$ & $(0.248)$ & $(0.0197)$ & $(0.203)$ & $(0.147)$ \\
DD (Treat X Time) & $-0.775^{* * *}$ & $-0.775^{* *}$ & $-1.009^{* * *}$ & $-1.641^{* * *}$ & $-1.641^{* * *}$ & $-1.662^{* * *}$ \\
& $(0.287)$ & $(0.289)$ & $(0.196)$ & $(0.117)$ & $(0.0946)$ & $(0.0892)$ \\
PT valid votes (\%) & $-0.112^{* * *}$ & $-0.112^{* * *}$ & $-0.0875^{* * *}$ & $0.0542^{* * *}$ & $0.0542^{* * *}$ & $0.0535^{* * *}$ \\
& $(0.00185)$ & $(0.0172)$ & $(0.0126)$ & $(0.000649)$ & $(0.00665)$ & $(0.00405)$ \\
Age (avg.) & $0.610^{* * *}$ & $0.610^{* * *}$ & $0.613^{* * *}$ & $-0.0690^{* * *}$ & $-0.0690^{* * *}$ & $-0.0881^{* * *}$ \\
& $(0.00380)$ & $(0.0636)$ & $(0.0567)$ & $(0.00115)$ & $(0.00921)$ & $(0.00384)$ \\
Schooling (avg.) & $-1.964^{* * *}$ & $-1.964^{* * *}$ & $-1.285^{* * *}$ & $-1.023^{* * *}$ & $-1.023^{* * *}$ & $-1.255^{* * *}$ \\
& $(0.0352)$ & $(0.652)$ & $(0.241)$ & $(0.0110)$ & $(0.152)$ & $(0.0714)$ \\
\hline R & 0.523 & 0.523 & 0.518 & 0.453 & 0.453 & 0.448 \\
Obs. & 53364 & 53364 & 53364 & 53364 & 53364 & 53364 \\
N.Clusters & - & 18 & 18 & - & 18 & 18 \\
\hline Robust SE & $\checkmark$ & & & $\checkmark$ & & $\checkmark$ \\
Clustered SE & & $\checkmark$ & $\checkmark$ & & $\checkmark$ \\
Municipal-level FE & & & $\checkmark$ & & $\checkmark$ \\
\hline \hline
\end{tabular}

Standard errors in parentheses

${ }^{*} p<0.10,{ }^{* *} p<0.05,{ }^{* * *} p<0.01$

Note: The unit of analysis is the voting station. Dependent variable is (\%) voter abstention (models 1-3) and the share (\%) of blank (discarded) votes (models 4-6). 


\section{E.2 Restricted sample}

Table 5: The effect of MUCT on voter abstention in general elections (Full sample)

\begin{tabular}{lcccccc}
\hline \hline & $(1)$ & $(2)$ & $(3)$ & $(4)$ & $(5)$ & $(6)$ \\
& Abstention & Abstention & Abstention & Blank & Blank & Blank \\
\hline \multirow{2}{*}{ Treat } & $1.259^{* * *}$ & $1.259^{* * *}$ & 0.213 & -0.143 & -0.143 & $0.658^{* * *}$ \\
& $(0.242)$ & $(0.307)$ & $(0.555)$ & $(0.104)$ & $(0.203)$ & $(0.159)$ \\
Time & $-0.138^{* *}$ & -0.138 & 0.186 & $1.645^{* * *}$ & $1.645^{* * *}$ & $1.782^{* * *}$ \\
& $(0.0541)$ & $(0.320)$ & $(0.248)$ & $(0.0197)$ & $(0.203)$ & $(0.147)$ \\
DD (Treat X Time) & $-0.775^{* * *}$ & $-0.775^{* *}$ & $-1.009^{* * *}$ & $-1.641^{* * *}$ & $-1.641^{* * *}$ & $-1.662^{* * *}$ \\
& $(0.287)$ & $(0.289)$ & $(0.196)$ & $(0.117)$ & $(0.0946)$ & $(0.0892)$ \\
PT valid votes (\%) & $-0.112^{* * *}$ & $-0.112^{* * *}$ & $-0.0875^{* * *}$ & $0.0542^{* * *}$ & $0.0542^{* * *}$ & $0.0535^{* * *}$ \\
& $(0.00185)$ & $(0.0172)$ & $(0.0126)$ & $(0.000649)$ & $(0.00665)$ & $(0.00405)$ \\
Age (avg.) & $0.610^{* * *}$ & $0.610^{* * *}$ & $0.613^{* * *}$ & $-0.0690^{* * *}$ & $-0.0690^{* * *}$ & $-0.0881^{* * *}$ \\
& $(0.00380)$ & $(0.0636)$ & $(0.0567)$ & $(0.00115)$ & $(0.00921)$ & $(0.00384)$ \\
Schooling (avg.) & $-1.964^{* * *}$ & $-1.964^{* * *}$ & $-1.285^{* * *}$ & $-1.023^{* * *}$ & $-1.023^{* * *}$ & $-1.255^{* * *}$ \\
& $(0.0352)$ & $(0.652)$ & $(0.241)$ & $(0.0110)$ & $(0.152)$ & $(0.0714)$ \\
\hline R & 0.523 & 0.523 & 0.518 & 0.453 & 0.453 & 0.448 \\
Obs. & 53364 & 53364 & 53364 & 53364 & 53364 & 53364 \\
N.Clusters & - & 18 & 18 & - & 18 & 18 \\
\hline Robust SE & $\checkmark$ & & & $\checkmark$ & & $\checkmark$ \\
Clustered SE & & $\checkmark$ & $\checkmark$ & & $\checkmark$ \\
Municipal-level FE & & & $\checkmark$ & & $\checkmark$ \\
\hline \hline
\end{tabular}

Standard errors in parentheses

${ }^{*} p<0.10,{ }^{* *} p<0.05,{ }^{* * *} p<0.01$

Note: The unit of analysis is the voting station. Dependent variable is (\%) voter abstention (models 1-3) and the share (\%) of blank (discarded) votes (models 4-6). 


\section{F Models with a placebo treatment}

\section{F.1 With controls}

Table 6: The effect of MUCT on voter abstention in general elections (Full sample)

\begin{tabular}{|c|c|c|c|c|c|c|}
\hline & $\begin{array}{c}(1) \\
\text { Abstention }\end{array}$ & $\begin{array}{c}(2) \\
\text { Abstention }\end{array}$ & $\begin{array}{c}(3) \\
\text { Abstention }\end{array}$ & $\begin{array}{c}(4) \\
\text { Blank } \\
\end{array}$ & $\begin{array}{c}(5) \\
\text { Blank } \\
\end{array}$ & $\begin{array}{c}(6) \\
\text { Blank } \\
\end{array}$ \\
\hline Treat & $\begin{array}{l}0.907^{* * *} \\
(0.0500)\end{array}$ & $\begin{array}{c}0.907^{* * *} \\
(0.322)\end{array}$ & $\begin{array}{l}1.411^{* *} \\
(0.575)\end{array}$ & $\begin{array}{l}0.818^{* * *} \\
(0.0176)\end{array}$ & $\begin{array}{c}0.818^{* * *} \\
(0.302)\end{array}$ & $\begin{array}{c}0.817^{* * *} \\
(0.198)\end{array}$ \\
\hline Time & $\begin{array}{l}0.421^{* * *} \\
(0.0479)\end{array}$ & $\begin{array}{c}0.421 \\
(0.301)\end{array}$ & $\begin{array}{l}0.535^{*} \\
(0.285)\end{array}$ & $\begin{array}{l}1.328^{* * *} \\
(0.0184)\end{array}$ & $\begin{array}{c}1.328^{* * *} \\
(0.176)\end{array}$ & $\begin{array}{c}1.488^{* * *} \\
(0.141)\end{array}$ \\
\hline DD (Treat X Time) & $\begin{array}{c}-0.156^{* * *} \\
(0.0586)\end{array}$ & $\begin{array}{l}-0.156 \\
(0.276)\end{array}$ & $\begin{array}{l}-0.142 \\
(0.299)\end{array}$ & $\begin{array}{c}0.0362^{*} \\
(0.0209)\end{array}$ & $\begin{array}{c}0.0362 \\
(0.0991)\end{array}$ & $\begin{array}{l}0.0716 \\
(0.104)\end{array}$ \\
\hline PT valid votes (\%) & $\begin{array}{c}-0.0983^{* * *} \\
(0.00123)\end{array}$ & $\begin{array}{c}-0.0983^{* * *} \\
(0.00940)\end{array}$ & $\begin{array}{c}-0.0836^{* * *} \\
(0.00721)\end{array}$ & $\begin{array}{c}0.0411^{* * *} \\
(0.000450)\end{array}$ & $\begin{array}{l}0.0411^{* * *} \\
(0.00577)\end{array}$ & $\begin{array}{l}0.0447^{* * *} \\
(0.00419)\end{array}$ \\
\hline Age (avg.) & $\begin{array}{c}0.576^{* * *} \\
(0.00282)\end{array}$ & $\begin{array}{l}0.576^{* * *} \\
(0.0499)\end{array}$ & $\begin{array}{l}0.579^{* * *} \\
(0.0436)\end{array}$ & $\begin{array}{l}-0.0698^{* * *} \\
(0.000875)\end{array}$ & $\begin{array}{c}-0.0698^{* * *} \\
(0.00728)\end{array}$ & $\begin{array}{r}-0.0833^{* * *} \\
(0.00555)\end{array}$ \\
\hline Schooling (avg.) & $\begin{array}{c}-1.815^{* * *} \\
(0.0292)\end{array}$ & $\begin{array}{c}-1.815^{* * *} \\
(0.453)\end{array}$ & $\begin{array}{c}-1.158^{* * *} \\
(0.166)\end{array}$ & $\begin{array}{l}-0.985^{* * *} \\
(0.00926)\end{array}$ & $\begin{array}{c}-0.985^{* * *} \\
(0.158)\end{array}$ & $\begin{array}{c}-1.175^{* * *} \\
(0.119)\end{array}$ \\
\hline $\mathrm{R}^{2}$ & 0.514 & 0.514 & 0.506 & 0.342 & 0.342 & 0.341 \\
\hline Obs. & 96629 & 96629 & 96629 & 96629 & 96629 & 96629 \\
\hline N.Clusters & - & 91 & 91 & - & 91 & 91 \\
\hline
\end{tabular}

Standard errors in parentheses

${ }^{*} p<0.10,{ }^{* *} p<0.05,{ }^{* * *} p<0.01$

Note: The unit of analysis is the voting station. Dependent variable is (\%) voter abstention (models 1-3) and the share (\%) of blank (discarded) votes (models 4-6). 